J. Appl. Glycosci., 57, 265-268 (2010)

(C) 2010 The Japanese Society of Applied Glycoscience

Note

\title{
Further Structural Study of the Xyloglucanase-derived Eggplant Xyloglucan Oligo-saccharides
}

(Received April 27, 2010; Accepted July 9, 2010)

\author{
Yoji Kato, ${ }^{1, *}$ Keiko Ota, ${ }^{2}$ Yutaka Hidano, ${ }^{3}$ Yasuo Azuma, ${ }^{2}$ Toru Onaka, ${ }^{4}$ Katsuro Yaoi $^{5}$ \\ and Yasushi Mitsuishi ${ }^{5}$ \\ ${ }^{1}$ Laboratory of Food Science, Faculty of Education, Hirosaki University \\ (1, Bunkyo-cho, Hirosaki 036-8560, Japan) \\ ${ }^{2}$ Development Department, Tohoku Chemical Co. \\ (3-1, Kanda 1-chome, Hirosaki 036-8061, Japan) \\ ${ }^{3}$ Department of Technology, Faculty of Education, Hirosaki University \\ (1, Bunkyo-cho, Hirosaki 036-8560, Japan) \\ ${ }^{4}$ Hiroka R\&D Inc. (2-1, Suehiro 1-chome, Hirosaki 036-8085, Japan) \\ ${ }^{5}$ The Institute for Biological Resources and Functions, National Institute of Advanced Industrial Science and Technology, \\ Tsukuba Central 6 (1-1-1, Higashi, Tsukuba 305-8566, Japan)

\begin{abstract}
Further structural study of the xyloglucanase-derived eggplant xyloglucan oligosaccharides was carried out to investigate the oligosaccharide units of xyloglucan from the cell-walls of eggplant in detail. The result shows that a hexasaccharide, $\mathrm{XSG}$, a heptasaccharide, $\mathrm{XX}_{2} \mathrm{GG}$, an octasaccharide, $\mathrm{LX} \mathrm{X}_{2} \mathrm{GG}$ and a nonasaccahride, LSGGG, in addition to the major oligosaccharides XXGG, LXGG, XLGG, XSGG, LLGG and LSGG, the structures of which were previously reported, are included in oligosaccharide units of eggplant xyloglucan.
\end{abstract}

Key words: eggplant, xyloglucan oligosaccharides, solanaceous vegetable, xyloglucanase

In our previous study, ${ }^{3)}$ we isolated a xyloglucan from the cell-walls of eggplant. This xyloglucan was hydrolyzed with a xyloglucan-specific endo-1,4- $\beta$-D-glucanase (xyloglucanase) from Penicillium sp. M451. ${ }^{4}$ The resulting hydrolyzate was fractionated by Bio-Gel P-2 chromatography. Hexa-, hepta- and octa-saccharide fractions were obtained in a ratio of 35:43:22 as major oligosaccharide fractions. The xyloglucan oligosaccharide fractions were separately subjected to sugar composition and methylation analyses, high-performance anion exchange chromatography with pulsed amperometric detection (HPAEC-PAD), and matrix-assisted laser-desorption ionization time of the flight mass spectrometry (MALDI-TOF-MS) before and after treatment with an isoprimeverose-producing oligoxyloglucan hydrolase (IPase) purified from Eupenicillium sp. $\mathrm{M}^{5}{ }^{5}$ or with $\beta$-D-galactosidase from Bacillus circulans. Hexa-, hepta- and octa-saccharide fractions might

\footnotetext{
* Corresponding author (Tel. \& Fax. +81-172-39-3436, E-mail ykato@cc.hirosaki-u.ac.jp).

Abbreviations: Ara, arabinose; Xyl, xylose; Glc, glucose; Gal, galactose; IP [ $\alpha$-D-Xyl-(1 $\rightarrow 6)$-D-Glc], isoprimeverose; XXGG, XSG, LXGG, XLGG, XX ${ }_{2} G G, X S G G$, LLGG, LX ${ }_{2} G G$, LSGG and LSGGG are the abbreviated names for xyloglucan oligosaccharides according to the nomenclature of Fry et al. [Ref. 1,2) Each $(1 \rightarrow 4)$ - $\beta$-linked D-glucosyl residue in the backbone is given a one-letter code according to its substituents: $G=\beta$-D-Glc; $X=\alpha$ D-Xyl- $(1 \rightarrow 6)-\beta-D-G l c ; \quad L=\beta-D-G a l-(1 \rightarrow 2)-\alpha-D-X y l-(1 \rightarrow 6)-\beta-D-$ Glc; $S=\alpha$-L-Ara- $(1 \rightarrow 2)-\alpha-D-X y l-(1 \rightarrow 6)-\beta-D-G l c ; X_{2}=\alpha$-L-Xyl$(1 \rightarrow 2)-\alpha$-D-Xyl- $(1 \rightarrow 6)-\beta$-D-Glc]. IPase, isoprimeverose-producing oligoxyloglucan hydrolase; HPAEC, high-performance anionexchange chromatography; PAD, pulsed amperometric detection; MALDI-TOF-MS, matrix-assisted laser-desorption ionization time of the flight mass.
}

consist mainly of XXGG, of XLGG, LXGG and XSGG, and of LSGG and LLGG, respectively. This work describes the structural characterization of other minor xyloglucanase-derived eggplant xyloglucan oligosaccharides. Unless otherwise stated, all materials and experimental procedures used for this study were the same as those described in a previous paper. ${ }^{3)}$

Xyloglucan was prepared from the cell-walls obtained from the edible portion of eggplants in a manner almost identical with that reported in a previous paper. ${ }^{3)}$ Eggplant xyloglucan $(100 \mathrm{mg}$ as Glc equiv. in $100 \mathrm{~mL}$ of $20 \mathrm{~mm}$ Na-acetate buffer, $\mathrm{pH} 5.5)$ was incubated at $40^{\circ} \mathrm{C}$ with Geotrichum sp. M128 xyloglucanase ${ }^{6}(0.2 \mathrm{U} / 0.1 \mathrm{~mL})$, the action pattern on xyloglucan polymers of which is the same as that of Penicillium sp. M451 xyloglucanase. ${ }^{4)}$ After reaction for $48 \mathrm{~h}$, the incubation mixture was heated for $10 \mathrm{~min}$ in a boiling water-bath, deionized with Amberlite IR-120 resin $\left(\mathrm{H}^{+}\right)$(about $3 \mathrm{~cm}^{3}$ ) and filtered through Toyo No. 5 paper. The filtrate (about $100 \mathrm{~mL}$ ) was concentrated to about $3 \mathrm{~mL}$. A portion of the concentrate was subjected to HPAEC analysis (Fig. 1). Peaks 6-A, 7-A, $-\mathrm{B}$, and $-\mathrm{D}$, and 8-A and -C corresponded to hexasaccharide XXGG, heptasaccharides LXGG, XLGG and XSGG, and octasaccharides LLGG and LSGG, respectively, which were characterized in a previous work $^{3}$ (Fig. 2).

The concentrate of M128-hydrolyzed eggplant xyloglucan was applied to a column $(2.3 \times 140 \mathrm{~cm})$ of Bio-Gel P-2 operated at $40^{\circ} \mathrm{C}$ and eluted with water; 4.2-mL fractions were collected and assayed for carbohydrate. Tubes 55-57, 58-61, 62-64 and 65-71 were separately combined, concentrated, and rechromatographed on the same column to give nona-, octa-, hepta-, hexa-saccharide fractions. 


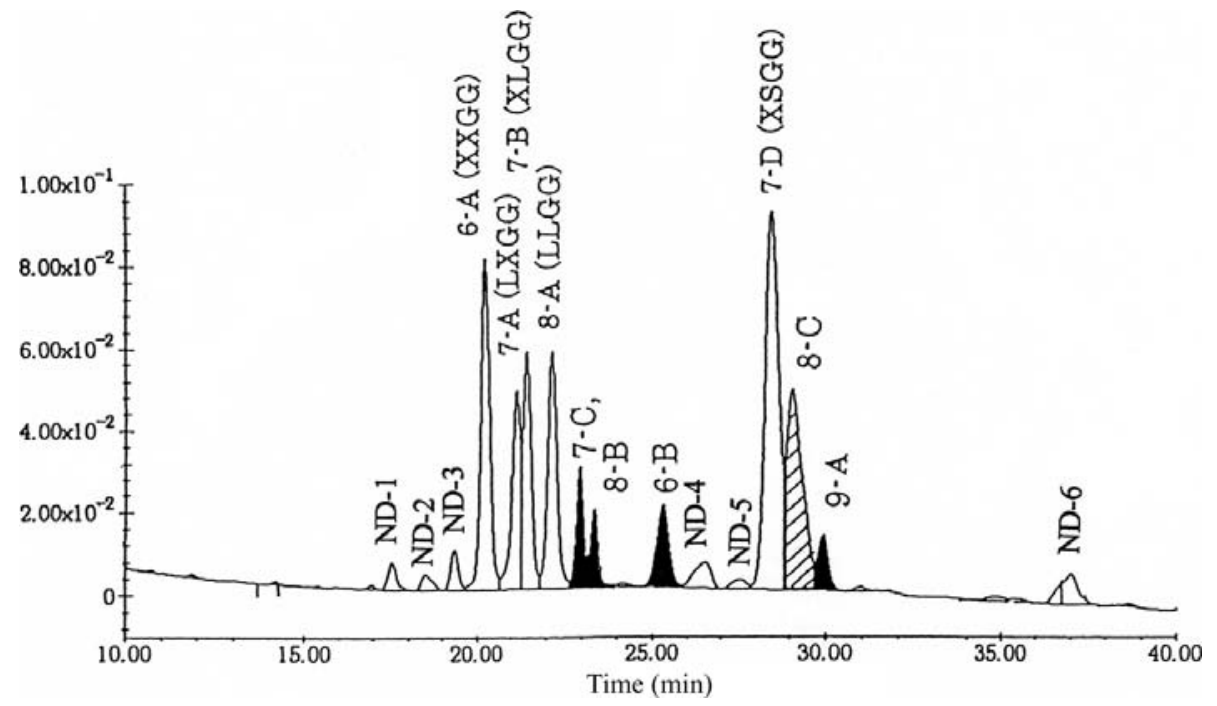

Hexasaccharide

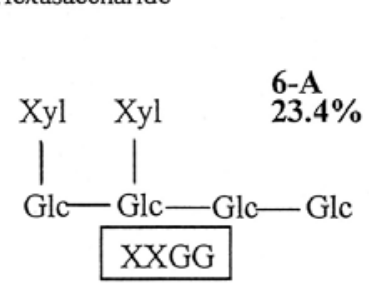

Fig. 1. Elution profile on HPAEC of $M$ 128 xyloglucanase-hydrolyzate of eggplant xyloglucan.

Peaks 6-A (13.9\% of total peak areas), 7-A (8.0\%), -B (8.9\%), and -D (23.0\%), and 8 -A (10.1\%) and $-\mathrm{C}(13.8 \%)$ corresponded to the hexasaccharide XXGG, heptasaccharides LXGG, XLGG and XSGG, and octasaccharides LLGG and LSGG, respectively, which were characterized in a previous work. ${ }^{3)}$ Hexasaccharide 6-B (4.6\%), heptasaccharide 7-C $(4.1 \%)$, octasaccharide 8-B $(2.6 \%)$ and nonasaccharide 9-A $(2.6 \%)$ were studied further after separation by HPLC. Oligosaccharide peaks ND-1 (1.0\%), -2 (0.8\%), $-3(1.4 \%),-4(2.0 \%),-5(0.6 \%)$ and -6 (2.6\%) were not subjected to structural analyses.

\section{Heptasaccharide}
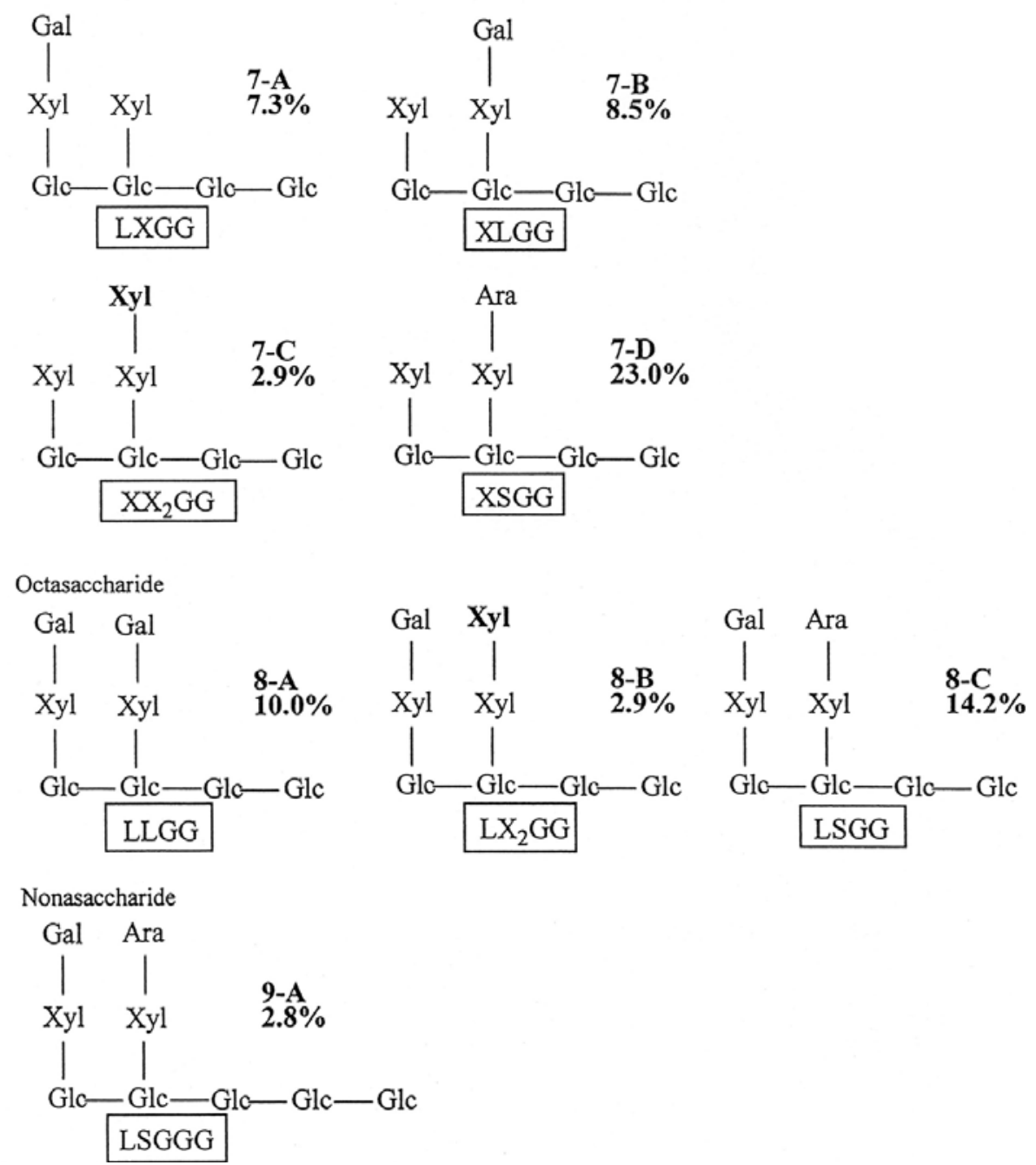

Fig. 2. Proposed structures of oligosaccharides isolated and purified from M-128-hydrolyzed eggplant xyloglucan.

Symbols: Glc, $\beta$-D-Glc-(1 $\rightarrow 4)-;$ Xyl, $\alpha-$

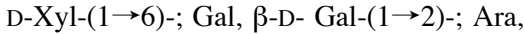
$\alpha$-L-Ara-(1 $\rightarrow 2)-; \quad$ Xyl, $\quad \alpha$-D-Xyl-( $1 \rightarrow 2)$-. Configurations of sugars are based on the substrate specificities of enzymes used, and on previous works. ${ }^{1-3,7-13)}$ Symbols in $\square$, see abbreviations. 
Then, each oligosaccharide fraction was separated by a preparative high-performance liquid chromatography (HPLC). Separations were performed at $20^{\circ} \mathrm{C}$ on a column $(7.8 \times 300 \mathrm{~mm})$ of TSKgel Amide-80 (TOSOH Co., Tokyo, Japan), using a flow rate of $2 \mathrm{~mL} / \mathrm{min}$. Oligosaccharides were eluted with $63 \%$ acetonitrile: $2 \mathrm{~mL}$ fractions were collected and assayed for carbohydrate. Each oligosaccharide was purified by repeating the preparative HPLC until a single peak elution pattern was obtained. Yields of hexasaccharides 6-A and 6-B, heptasaccharides 7-A, 7-B, 7-C and 7-D, octasaccharides 8-A, 8-B, and 8-C, and nonasaccharide 9-A were 3.7, 3.6, 1.0, 1.7, 0.5, $15.9,5.8,1.0,3.2$ and $2.3 \mathrm{mg}$, respectively. Hexasaccharide 6-B, heptasaccharide $\mathbf{7 - C}$, octasaccharide 8-B and nonasaccharide 9-A were studied further.

Heptasaccharide 7-C (yield: $0.5 \mathrm{mg}$ ). Sugar composition analysis showed that 7-C consisted of Glc and Xyl in a molar ratio of 4:3. The heptasaccharide was subjected to MALDI-TOF-MS analysis. In the mass spectrum, the peak at $m / z$ 1086.34, which corresponds to the molecular ion as sodium adduct $[\mathrm{M}+\mathrm{Na}]^{+}$of (hexose $)_{4}(\text { pentose })_{3}$, was observed. Based on the sugar composition of the heptasaccharide, (hexose) $)_{4}(\text { pentose })_{3}$ may correspond to $(\mathrm{Glc})_{4}$ $(\mathrm{Xyl})_{3}$. The branching pattern and the arrangement of the Glc residues in the oligosaccharide, $(\mathrm{Glc})_{4}(\mathrm{Xyl})_{3}$ were investigated as follows.

First, the heptasaccharide 7-C was treated with M9 IPase which splits off isopromeverose units from the nonreducing end of the backbone of the xyloglucan oligosaccharide and cannot by-pass the glucosyl residues replaced with $\beta$-Gal-( $1 \rightarrow 2)-\alpha$-Xyl, or $\alpha$-Fuc- $(1 \rightarrow 2)-\beta$-Gal- $(1 \rightarrow 2)$ $\alpha$-Xyl side chains. The hydrolysis product was subjected to HPAEC analysis. An oligosaccharide (I) and isoprimeverose were found in the product. Oligosaccharide (I) was obtained by preparative HPLC in a yield of about $0.2 \mathrm{mg}$ (as Glc equiv.). On acid hydrolysis, oligosaccahride (I) gave Glc and Xyl in the molar ratio of 3:2. In the MALDI-TOF-MS spectrum of oligosaccharide (I), a peak at $\mathrm{m} / \mathrm{z} 792.597$ corresponding to [(hexose) $)_{3}$ (pentose $\left.)_{2}+\mathrm{Na}\right]^{+}$was observed. It is clear that $\mathrm{Xyl}$ residues link to the non-reducing end of Glc residues in oligosaccharide (I). Next, oligosaccharide (I) was treated with $\beta$-xylosidase, but not hydrolyzed. This oligosaccharide was not studied further because of its low yield. Sims et al. obtained a small amount of an octasaccharide consisting of Glc: Xyl in a ratio of 5:3 from xyloglucan polysaccharide secreted by suspension-cultured cells of Nicotiana plumbaginifolia, which belongs to the solanaceous plants, as does eggplant, and reported the presence of the 4,6-Glc residue replaced with $\alpha$-D-Xyl- $(1 \rightarrow 2)-\alpha$-D-Xyl- in the octasaccharide, $\mathrm{XX}_{2} \mathrm{GGG}$ and/or $\mathrm{X}_{2} \mathrm{XGGG}^{2}$. This supports that oligosaccharide (I) may be $\mathrm{X}_{2} \mathrm{GG}$, the non-reducing end of Glc residues in the backbone of which is replaced with $\alpha$-D-Xyl- $(1 \rightarrow 2)-\alpha-D-X y l-$. On the basis of the modes of action of M128 xyloglucanase and M9 IPase, it is reasonable to consider that heptasaccharide 7-C may be $\mathrm{XX}_{2} \mathrm{GG}$ [(hexose $)_{4}(\text { pentose })_{3}$ ], which is hydrolyzed into isoprimeverose and $\mathrm{X}_{2} \mathrm{GG}$ by treatment with IPase. The structure of 7-C is proposed to be $\mathrm{XX}_{2} \mathrm{GG}$ as shown in Fig. 2.

Octasaccharide 8 -B (yield: $1.0 \mathrm{mg}$ ). Sugar composi- tion analysis showed that octasaccharide 8-B consisted of Glc, Xyl, and Gal in a molar ratio of 4:3:1. The octasaccharide was subjected to MALDI-TOF-MS analysis. In the mass spectrum, the ion peak at $m / z$ 1246.53, which corresponds to the molecular ion as sodium adduct $\left[(\text { hexose })_{5}(\text { pentose })_{3}+\mathrm{Na}\right]^{+}$of the octasaccharide, was observed. From the sugar composition of $\mathbf{8 - B}$, the octasaccharide (hexose $)_{5}(\text { pentose })_{3}$ may correspond to $(\mathrm{Glc})_{4}(\mathrm{Xyl})_{3}$ $(\mathrm{Gal})_{1}$. The branching pattern and the arrangement of the Glc residues in 8-B, $(\mathrm{Glc})_{4}(\mathrm{Xyl})_{3}(\mathrm{Gal})_{1}$ were investigated as follows. First, oligosaccharide 8-B was treated with IPase and the product was subjected to HPAEC and MALDI-TOF-MS analyses. Both results showed that oligosaccharide 8-B was not hydrolyzed by treatment with IPase. This means that Xyl residue linked to the nonreducing end of Glc residues in the backbone is replaced with Gal residue or Xyl residue. Next, oligosaccharide 8-B was treated with $\beta$-D-galactosidase, and then treated with IPase. HPAEC analysis showed that the final hydrolyzate consisted of Gal, isoprimeverose and a pentasaccharide consisting of Glc and Xyl in a molar ratio of 3:2. Analyses of the pentasaccharide, which was purified by preparative HPLC, showed that the structure of pentasaccharide was the same as that of oligosaccahride (I). On the basis of the modes of action of M128 xyloglucanase and M9 IPase, it is reasonable to consider that octasaccharide 8-B may be $\mathrm{LX}_{2} \mathrm{GG}\left[(\text { hexose })_{5}(\text { pentose })_{3}\right.$ ], which is hydrolyzed into isoprimeverose and $\mathrm{X}_{2} \mathrm{GG}$ by treatment with IPase after hydrolysis with $\beta$-D-galactosidase. The structure of 8-B is proposed to be $\mathrm{LX}_{2} \mathrm{GG}$ as shown in Fig. 2.

Hexasaccharide 6-B (yield: $3.6 \mathrm{mg}$ ). Sugar composition analysis showed that 6-B consisted of Glc, Xyl and Ara in a molar ratio of $3: 2: 1$. In the MALDI-TOF-MS spectrum, the peak at $m / z$ 923.647, which corresponds to the molecular ion as sodium adduct $[\mathrm{M}+\mathrm{Na}]^{+}$of (hexose $)_{3}$ (pentose) $)_{3}$, was observed. From the sugar composition of the hexasaccharide, (hexose $)_{3}$ (pentose $)_{3}$ may correspond to $(\mathrm{Glc})_{3}(\mathrm{Xyl})_{2}(\mathrm{Ara})_{1}$. Hexasaccharide 6-B was treated with M9 IPase and the product was subjected to HPAEC analysis. An oligosaccharide (II) and isoprimeverose were found in the product. Oligosaccharide (II) was obtained by preparative HPLC. On acid hydrolysis, oligosaccahride (II) gave Glc, Xyl and Ara in the molar ratio of $2: 1: 1$. On the basis of the modes of action of M128 xyloglucanase and M9 IPase and of the previous results, it is reasonable to consider that hexasaccharide 6-B may be XSG $\left[(\text { hexose })_{3}(\text { pentose })_{3}\right]$, which is hydrolyzed into isoprimeverose and SG by treatment with IPase. The structure of $\mathbf{6 - B}$ is proposed to be XSG as shown in Fig. 2.

Nonasaccharide 9-A (yield: $2.3 \mathrm{mg}$ ). Sugar composition analysis showed that nonasaccharide 9-A consisted of Glc, Xyl, Gal and Ara in a molar ratio of 5:2:1:1. Nonasaccharide 9-A was treated with IPase and the product was subjected to HPAEC and MALDI-TOF-MS analyses. Both results showed that oligosaccharide 9-A was not hydrolyzed by treatment with IPase. This means that Xyl residue linked to the non-reducing end of Glc residues in the backbone is replaced with Gal residue or Ara residue. Next, oligosaccharide 9-A was treated with $\beta$-D- 
galactosidase, and then treated with IPase. HPAEC analysis showed that the final hydrolyzate consisted of Gal, isoprimeverose and oligosaccharide (III) consisting of Glc, Xyl and Ara in a molar ratio of 4:1:1. On the basis of the modes of action of M128 xyloglucanase and M9 IPase, it is reasonable to consider that oligosaccharide (III) may be LSGGG [(hexose $)_{4}(\text { pentose })_{2}$, which is hydrolyzed into isoprimeverose and SGGG by treatment with IPase after hydrolysis with $\beta$-D-galactosidase. The structure of $\mathbf{9 - A}$ is proposed to be LSGGG as shown in Fig. 2.

In a previous work $^{3)}$ we reported that eggplant xyloglucan is composed mainly of XXGG, XLGG, LXGG, XSGG, LSGG and LLGG. Namely, eggplant xyloglucan is built from XXGG-type subunits. The present result shows that a hexasaccharide, XSG (4.9\%), a heptasaccharide, $\mathrm{XX}_{2} \mathrm{GG}$ (2.9\%), an octasaccharide $\mathrm{LX}{ }_{2} \mathrm{GG}(2.9 \%)$, and a nonasaccahride, LSGGG $(2.8 \%)$, in addition to the major oligo-saccharides XXGG (23.4\%), XLGG (8.5\%), LXGG (7.3\%), XSGG (23.0\%), LSGG (14.2\%), and LLGG (10.0\%) are included in oligosaccharide units of eggplant xyloglucan (Fig. 2). The ratio of oligosaccharides was calculated on the basis of peak areas of each step of chromatography. Furthermore, the present study revealed regions consisting of one and three Glc residues which are not xylosylated at $O-6$ in the $\beta-1,4-\mathrm{D}$-glucan backbone of eggplant xyloglucan.

\section{REFERENCES}

1 ) S.C. Fry, W.S. York, P. Albersheim, A. Darvill, T. Hayashi, J. P. Joseleau, Y. Kato, E.P. Lorences, G.A. Maclachlan, M. McNeil, A.J. Mort, J.S.G. Reid, H.U. Seitz, R.R. Selvendran, A.G.J. Voragen and A.R. White: An unambiguous nomenclature for xyloglucan-derived oligosaccharides. Physiol. Plant., 89, 1-3 (1993).

2 ) I.M. Sims, S.L.A. Munro, G. Currie, D. Craik and A. Bacic: Structural characterization of xyloglucan secreted by suspension-cultured cells of Nicotiana plumbaginifolia. Carbohydr. Res., 293, 147-172 (1996).

3 ) Y. Kato, T. Konishi, Y. Hidano and Y. Mitsuishi: Structural analysis of the eggplant xyloglucan by xyloglucanase. J. Appl. Glycosci., 51, 93-99 (2004).

4 ) Y. Mitsuishi and Y. Kosugi: A novel enzyme hydrolyzing xyloglucan of Penicillum sp. M451. Nippon Nogeikagaku Kaishi, 67, 581 (1993).

5 ) Y. Mitsuishi, T. Kato and Y. Kosugi: Characterization of isoprimeverose producing enzyme produced by fungal strain M9. in Abstracts of Papers, Society for Fermentation and Bioengineering, Osaka, p. 103 (1992).

6 ) K. Yaoi and Y. Mitsuishi: Purification, characterization, cDNA cloning, and expression of a xyloglucan endoglucanase from Geotrichum sp. M128. FEBS Lett., 560, 45-50 (2004).

7 ) Y. Kato and K. Matsuda: Examination of the fine structures of xyloglucans using endo-( $1 \rightarrow 4)-\beta$-D-glucanases. in Methods in Carbohydrate Chemistry, Vol. X, J.N. BeMiller, D.J. Manners, R.J. Sturgeon and R.L. Whistler, eds., John Wiley \& Sons, Inc., New York, p. 207-216 (1994).

8 ) S. Eda and K. Kato: An arabinoxyloglucan isolated from the midrib of the leaves of Nicotiana tabacum. Agric. Biol. Chem., 42, 351-357 (1978).

9 ) M. Mori, S. Eda and K. Kato: Two xyloglucan oligosaccharides obtained by cellulase-degradation of tobacco arabinoxyloglucan. Agric. Biol. Chem., 43, 145-149 (1979).

10) S.G. Ring and R.R. Selvendran: An arabinogalactoxyloglucan from the cell wall of Solanum tuberosum. Phytochemistry, 20, 2511-2519 (1981)

11) J.-P. Vincken, A.J.M. Wijsman, G. Beldman, W.M.A. Niessen and A.G.J. Voragen: Potato xyloglucan is built from XXGGtype subunits. Carbohydr. Res., 288, 219-232 (1996).

12) W.S. York, V.S.K. Kolli, R. Orlando, P. Albersheim and A.G. Darvill: The structures of arabinoxyloglucans produced by solanaceous plants. Carbohydr. Res., 285, 99-128 (1996).

13) T. Konishi, Y. Mitsuishi and Y. Kato: Analysis of the oligosaccharide units of xyloglucans by digestion with isoprimeverose-producing oligoxyloglucan hydrolase followed by anion-exchange chromatography. Biosci. Biotechnol. Biochem., 62, 2421-2424 (1998).

\section{キシログルカナーゼ由来 \\ 茄子キシログルカンオリゴ糖の構造解析}

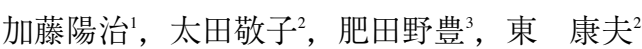

大中 徹4, 矢追克郎 ${ }^{5}$ ，三石 安 ${ }^{5}$

1 弘前大学教育学部食物学研究室

(036-8560 弘前市文京町 1)

2 東北化学薬品株式会社開発部

(036-8061 弘前市神田 1-3-1)

${ }^{3}$ 弘前大学教育学部技術科教室

(036-8560 弘前市文京町 1)

${ }^{4}$ 弘果総合研究開発株式会社

(036-8085 弘前市末広 1-2-1)

5 独立行政法人産業技術総合研究所つくば中央第六事業所

(305-8566 つくば市東 1-1-1)

茄子キシログルカンを構成しているオリゴ糖単位を詳 細に調べるために, 前回報告したキシログルカナーゼ由 来の主要キシログルカンオリゴ糖 [六糖 $(\mathrm{XXGG})$, 七糖 (LXGG，XLGG，XSGG) および八糖 (LLGG, XSGG)] 以 外のオリゴ糖について構造を解析した。 その結果, 新た に六糖として XSG，七糖として $\mathrm{XX}_{2} \mathrm{GG}$ ，八糖として $\mathrm{LX}_{2} \mathrm{GG}$ ，九糖として LSGGGの存在が確認された。 [XXGG 等は Fry らによるキシログルカンオリゴ糖の表示 法で, 主鎖の各 $(1 \rightarrow 4)-\beta$ 結合のグルコース残基の分岐様 式により一文字コードで示される，G= $\beta-D-G l c ， X=\alpha-D-$ Xyl-( $(1 \rightarrow 6)-\beta$-D-Glc, $\quad L=\beta-D-G a l-(1 \rightarrow 2)-\alpha$-D-Xyl- $(1 \rightarrow 6)-\beta$-DGlc, $S=\alpha$-L-Ara- $(1 \rightarrow 2)-\alpha-\mathrm{D}-\mathrm{Xyl}-(1 \rightarrow 6)-\beta-\mathrm{D}-\mathrm{Glc}, \mathrm{X}_{2}=\alpha-\mathrm{D}-$ Xyl-(1 $1 \rightarrow 2)-\alpha-D-X y l-(1 \rightarrow 6)-\beta-D-G l c]$. それぞれの単位オリ ゴ糖の各種クロマトのピーク面積から算出した割合は,

XXGG : XSG : LXGG : XLGG : $\mathrm{XX}_{2} \mathrm{GG}$ : XSGG : LLGG $:$ LX $_{2} \mathrm{GG}:$ LSGG $:$ LSGGG=23.4 : $4.9: 7.3: 8.5:$ $2.9: 23.0: 10.0: 2.9: 14.2: 2.8$ であった。 